Article

\title{
Planning for the Enhancement of the Modern Built Heritage in Thessaly Region: The Case of the "Konakia" Monuments
}

\author{
Aikaterini Papandreou ${ }^{1, *}$ and Marilena Papageorgiou ${ }^{2}$ \\ 1 Department of Planning and Regional Development, University of Thessaly, 38334 Volos, Greece \\ 2 Department of Planning and Development, Aristotle University of Thessaloniki, 54124 Thessaloniki, Greece \\ * Correspondence: kpapandreou@yahoo.gr
}

Received: 4 June 2019; Accepted: 20 July 2019; Published: 22 July 2019

check for updates

\begin{abstract}
Built heritage constitutes an invaluable asset to be treasured and wisely managed in order to avoid loss of place identity, cultural and social degradation and loss of leisure and tourism opportunities. The present paper focuses on the modern built heritage of the Thessaly Region (Greece), giving special emphasis to the "konakia" monuments built during the late 19th and early 20th century that were once used as residences by the big landowners of the Thessalian agricultural plain ("tsiflikia"). Field research conducted, as well as a survey of secondary data, revealed that only fifteen (15) "konakia" remain in Thessaly, equally dispersed in Larisa, Trikala and Karditsa Prefectures. Given their use, all of the "konakia" are found within—or in the vicinity of-agricultural land and settlements. Most of them present severe signs of abandonment, while only four (4) of them are in use (either as second-homes or as spaces with cultural and administrative use). Starting in 1979 (until 2005), with the exception of the Averof "konakia", all of the rest have been designated as part of the modern built heritage of Greece. Considering these facts-and that most of such properties are private-the paper proposes a six (6) step methodology, for their wise management and integration in the spatial and cultural landscape of Thessaly: (1) Selection of the proper type of (re)use of the monument(s), (2) selection (or reconsideration) of the protection status and zoning, (3) identification of the urban regeneration interventions, (4) introduction of the necessary amendments to the urban/local plan, (5) selection of the proper financial tools and (6) selection of the proper marketing strategy. The paper concludes by highlighting the need to address the "konakia" as a set of monuments, to achieve stakeholders' engagement and local community involvement, without undermining either protection status or the private rights of owners over these cultural properties.
\end{abstract}

Keywords: modern built heritage; spatial management and protection; konakia; Thessaly (Greece)

\section{Introduction}

Cultural heritage constitutes an invaluable asset from a historical, cultural, social and economic point of view. Therefore, it should be treasured and wisely managed in order to avoid loss of place identity, cultural and social degradation, and loss of leisure and tourism opportunities [1,2].

At an international level, the enhancement and management of cultural heritage gained momentum and attention in the mid-20th century. Nowadays, the modern concept of sustainable management is based on the holistic and integrated perception of all the dimensions embedded in cultural heritage assets, e.g., physical, spatial, economic, social, historical, and symbolic [3]. It presupposes an interdisciplinary approach to the study and protection of monuments and the active participation of the local community, as well as adaptations according to the peculiarities of each case and changing socio-economic conditions. 
Given this context, the present paper deals with issues of sustainable management of the modern built heritage of the Thessaly Region (Greece), giving special emphasis to the "konakia" monuments, built during the late 19th and early 20th centuries, which used to be residences for the big landowners of Thessalian agricultural land ("tsiflikia"). The ultimate aim of this paper is to make proposals for the sustainable management of the "konakia" monuments, always taking into account the fact that they are a special type of built and architectural heritage belonging to the recent past, and that they are still under private ownership, a fact that puts specific limitations on their enhancement and preservation.

This paper is divided into five sections. Following the introduction, the second section puts forward the methodological and the theoretical framework of the research, mainly focusing on the management and the spatial planning approaches that are suitable for cultural heritage properties. The third presents the results of the research carried out on the monuments in question, including an analysis of the field and desk research (identifying the key spatial features of the "konakia" monuments), and a simple methodology with the steps to be made towards the wise management of cultural properties such as the "konakia". In the fourth section, a case study is selected (the Harokopos tower "konakia"). Finally, the fifth section contains concluding remarks and proposals for the wise and sustainable management of the "konakia" monuments, adopting the most suitable planning and management approaches.

\section{Methodological and Theoretical Framework}

\subsection{The Methodology of the Research}

The research conducted for this paper was divided into two parts: the theoretical part and a case study. The key theoretical issues included: (a) theoretical approaches to the optimal management of the cultural and built heritage, (b) the latest discussions as to how to expand the use of environmental economics in cultural heritage, and thus set priorities for management and planning, and (c) suitable spatial planning tools and models provided by Greek legislation for the optimal management of te cultural and built heritage. This theoretical framework is presented in brief in the next section (Section 2.2).

The case study was based on: (a) desk and bibliographic research, and (b) field research, to identify and record the key spatial characteristics of the "konakia" monuments. This research took place at the premises of the Thessaly Region Authority, where important (and historical) files and archives are kept for all types of monuments in its area of jurisdiction. Literature on the history of Thessaly (as well as on the transition from the feudal system to the current legal property rights) was also referenced. In addition, on-site visits to all the "konakia" monuments took place, making possible the collection of necessary data and photographic documents.

The information gathered for each monument from both the desk and the field research, was recorded on a special Registration Form, which included the following information (per monument): historical background; geographical features (location, etc.); spatial features (existing Plans, land-use regulations and other restrictions; architectural and morphological features; property status; use and physical conditions; protection status (e.g., official designations); and a short real estate valuation. In addition, the field research also permitted the compilation of a photo gallery, including valuable snapshots of the remaining "konakia" monuments. Essential data for the research (which was especially useful for the formation of proposals) was also derived from selective interviews with key executives and officials in the Thessaly Region.

\subsection{Theoretical Approaches and Tools for the Management and Protection of Cultural Heritage}

In the international literature and in practice, there are considered to be three key approaches for cultural heritage management: a) the material-based approach, b) the value-based approach, and c) the living monument/heritage approach $[4,5]$. 
(a) The material-based approach, endorsed by the Venice Charter (ICOMOS, 1964), is mainly expert-driven, placing the greatest emphasis on the preservation of the material/fabric of a monument. This approach puts conservation in the hands of heritage authorities (mostly state-appointed), while the local community is not taken into account. (b) The value-based approach is currently the most widely preferred for heritage conservation, especially in the United States, Canada and Australia. It is largely based on the Burra Charter (ICOMOS, 1999), and it focuses on the values that society (consisting of various stakeholders) ascribes to heritage. Here, the community is placed at the core of conservation. (c) Finally, the "living" monument/heritage approach places the living dimension of heritage at the core of decision-making and considers continuity as the key theme. It emerged about three decades ago from ICCROM, and it has been embraced mostly by non-western civilisations. The "living" monument approach recognises communities as the true long-term custodians of their heritage sites and empowers them in the conservation and managing process, so they can benefit from their traditional (and established) values, management systems and maintenance practices. In this approach, conservation is interlinked with the sustainable development of the communities.

Of equal importance to the above management approaches are also those referring to planning issues. One of the prevailing planning approaches is included in the UNESCO Recommendation on the Historic Urban Landscape that was adopted in 2011 [6,7]. A key characteristic of this approach is that it is holistic, meaning that it integrates both the goals of urban heritage conservation and those of social and economic development. Beyond the physical environment, the human environment is equally considered, also placing emphasis on both tangible and intangible qualities [8,9]. The Historic Urban Landscape approach seeks to support the integration of environmental, social and cultural concerns into the implementation of urban planning and development. Other important planning approaches that were initially launched to address natural heritage, but were eventually used in cultural heritage, too, relate to spatial and protection planning. According to Kozlowski and Vas-Bowen [10], buffer zone planning (BZP) is considered to be the key approach to fill the gap between conservation and wise management of cultural heritage. In this case, too, lessons learnt from natural heritage areas confirm that BZP is an ideal method for implementing gradual protection in the surrounding area of a protected space, without hampering any types of activities and development outside its bounds [11].

In Greece, protection zoning for monumental and cultural heritage has long been addressed by both the Ministry of Culture and the Ministry for the Environment [11]. On the part of the Ministry of Culture, the most recent legislation (L.3028 of 2002) concerning the cultural heritage of the country launches two types of protection zones: Protection Zone A and Protection Zone B. Protection Zone A provides for the absolute protection of the area that usually includes, exclusively and strictly, the location of the monument or archaeological site; all kinds of interventions and constructions are prohibited. Protection Zone B acts as a Buffer Zone, extending to such a distance as to include areas that interact with the monument and its surrounding landscape (so that special planning regulations are applied). On the part of the Ministry for the Environment, environmental and spatial planning legislation also provides for special zoning to protect the built and monumental heritage of the country, although in an indirect way. Special Protection Areas (ПЕП) are special zones that can be used in Local Spatial Plans (Urban Plans, etc.), in order to implement very strict building regulations, and thus to achieve protection of the cultural, natural and agricultural landscapes. In the past, however, spatial planning legislation also provided another special zone called the Zone for Building Activity Control (ZOE) that is now outdated and is no longer used. Sites of Outstanding Natural Beauty (TIФK) is another special zone, suitable for the protection of built and monumental heritage in rural areas; it was conceptualised in the 1950s (L.1469) by the Ministry of Culture, but then transferred in the recent past (in 2011) to the Ministry for the Environment, which now has absolute jurisdiction over such zones (see Table 1). 
Table 1. Zoning launched by the Greek legislation (and per Ministry).

\begin{tabular}{|c|c|}
\hline \multicolumn{2}{|r|}{ Planning Zones under the jurisdiction of the Ministry of Culture } \\
\hline 1950 & Landscapes of Outstanding Natural Beauty (in 2011 transferred to the Ministry for the Environment) \\
\hline 2002 & Protection Zone A and Protection Zone B \\
\hline \multicolumn{2}{|r|}{ Planning Zones under the jurisdiction of the Ministry for the Environment } \\
\hline 1983 & Zones for Building Activity Control (ZOE) (outdated zone) \\
\hline 1997 & Special Protection Area (ПЕП) (included in Local Spatial Plans / Urban Plans) \\
\hline
\end{tabular}

Source: Papageorgiou, 2015 [11].

Beyond the above, and also recently gaining momentum in the international literature, is the use of ecological economics and economic valuation techniques to achieve sustainable management of cultural heritage. Given the non-extractive character of most values associated with cultural heritage, the central objective of these evaluation techniques is to translate and express tangible and intangible qualities, functions and uses of cultural assets into economic (monetary) terms [12,13]. In these techniques, the focus is to measure the benefits humans receive from goods or services deriving from cultural heritage assets, as well as to measure the socio-cultural qualities embedded in these assets $[14,15]$. This task requires a thorough comprehension of both the "market" and the "nonmarket" values of cultural assets. As far as "market" values are concerned, these are mainly associated with recreation and tourism activities (that may result in the generation of income). On the other hand, as far as "nonmarket" values are concerned, these may be associated with historical, artistic, social, spiritual, and symbolic qualities, i.e., qualities that are not easily identified by markets [16].

Evaluation of values associated with cultural heritage assets-although difficult-is an essential task in order to decide the type of re-use and protection that is appropriate for a monument. In addition, despite the limitations of these techniques, knowing and acknowledging the value of cultural heritage is essential for stakeholders and decision-makers in order to identify the costs and benefits of restoration and preservation and thus, set the priorities in planning and management implementations [17], to achieve optimal integration of each monument in the cultural, social and economic environment.

\section{The Case of the "Konakia" Monuments in the Thessaly Region}

\subsection{General and Historical Information on the Study Area and the "Konakia"}

Thessaly is a historical region of Greece, located in the central continental area of the country. The Thessaly Region covers a surface area of $14,037 \mathrm{~km}^{2}$ (10.6\% of the country). According to the 2011 Census, it has a population of 320,762 inhabitants ( $6.78 \%$ of the country's population). The region includes the largest agricultural plain in Greece, and consequently has a strong agricultural history and identity that has long been reflected in the tangible and intangible aspects of everyday life.

Historically, Thessaly region was conquered by the Ottomans in 1423, but was liberated in 1881 and subsequently incorporated into the new Greek State. During the late Ottoman period (late 18th century-early 19th century), large properties were formed ("tsiflikia"), which covered more than $2 / 3$ of the agricultural land of Thessaly and employed almost half of its population [18]. By rule, each of the "tsiflikia" had power over one or more villages. At that period, from a total of about 650 villages in the Thessaly plain, about 450 villages were under the jurisdiction of the local "tsiflikia" [19].

Shortly before the liberation of Thessaly, the Ottoman owners of the "tsiflikia" sold their properties to wealthy Greek merchants and entrepreneurs who lived abroad. The new legal framework of the Greek State notably worsened the working conditions of the peasants and caused social unrest (and occasionally bloody clashes) in the entire region, contributing to the creation of the so-called Agricultural Issue of Thessaly. This problem remained without a solution for more than four decades. It was finally resolved after 1923, when the land of the "tsiflikia" was expropriated and distributed by the government to local peasants and Greek refugees from Asia Minor that had settled in Thessaly. The redistribution of the agricultural land that took place in Thessaly presents great similarities to 
measures taken in England following the Enclosure Acts [20,21], in Italy after the elimination of the feudal system [22-24], and so on.

The villages within the "tsiflikia" had a specific social and spatial structure. Each settlement included the poorly constructed houses of the peasants and the residence of the landowner and his family. The latter, known as "konakia", were large stone-built manor houses, often fortified. Their main building usually included a small tower, which was used as an observatory of the neighbouring land, and was surrounded by smaller auxiliary buildings, such as a warehouse, a stable, etc., inside a walled courtyard. The "konakia" usually housed the land management foreman and other employees, serving as the administrative centres of the "tsiflikia", as well as landmarks for the local population or visitors to the area (see Figure 1). Only a small number of them were built before 1881, while the majority were built later by the Greek landowners.

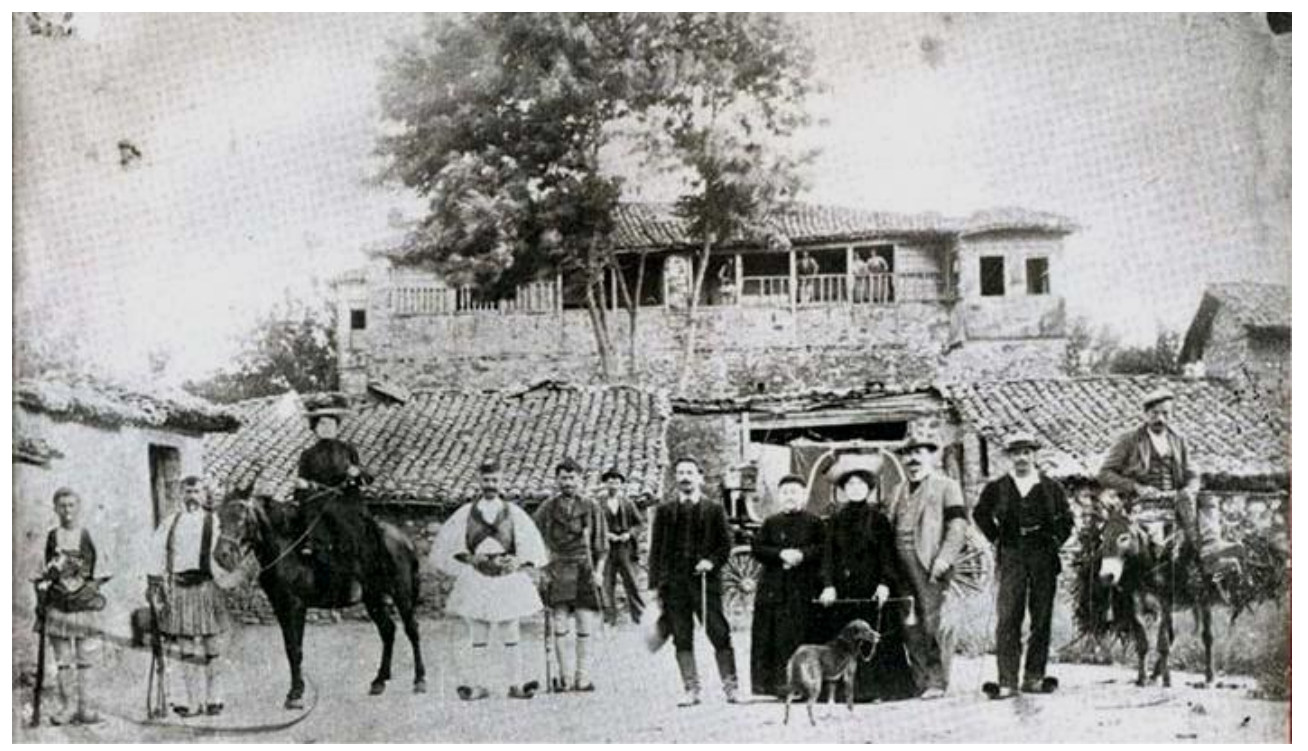

Figure 1. "Konakia" in Vlitsaki Tsifliki (end of 19th century). Source: Modern Hellenic History (1770-2000) [16].

\subsection{Key Spatial Characteristics of the "Konakia" Monuments}

Following desk and field research in the Thessaly Region, a special Registration Form was filled in for each of the "konakia" monuments (see Section 2.1). The key characteristics that were identified following this research and the completion of these Forms are presented below:

Location and geographical characteristics: In the study area (Thessaly Region), only 15 "konakia" monuments remain today (see Figure 2 and Table 2). Among those, six (6) are found in the Larissa Regional Unit (Harokopos in Giannouli, Harokopos in Polyneri, Baltzis, Papageorgiou, Hatzigakis, Averof); five (5) are found in the Trikala Regional Unit (Zournatzis, Zappas, Zavitsanos, Koutsekis, Mekios); and four (4) in the Karditsa Regional Unit (Moufoubeis, Cohen, Zografos G, Zografos Ch.). 


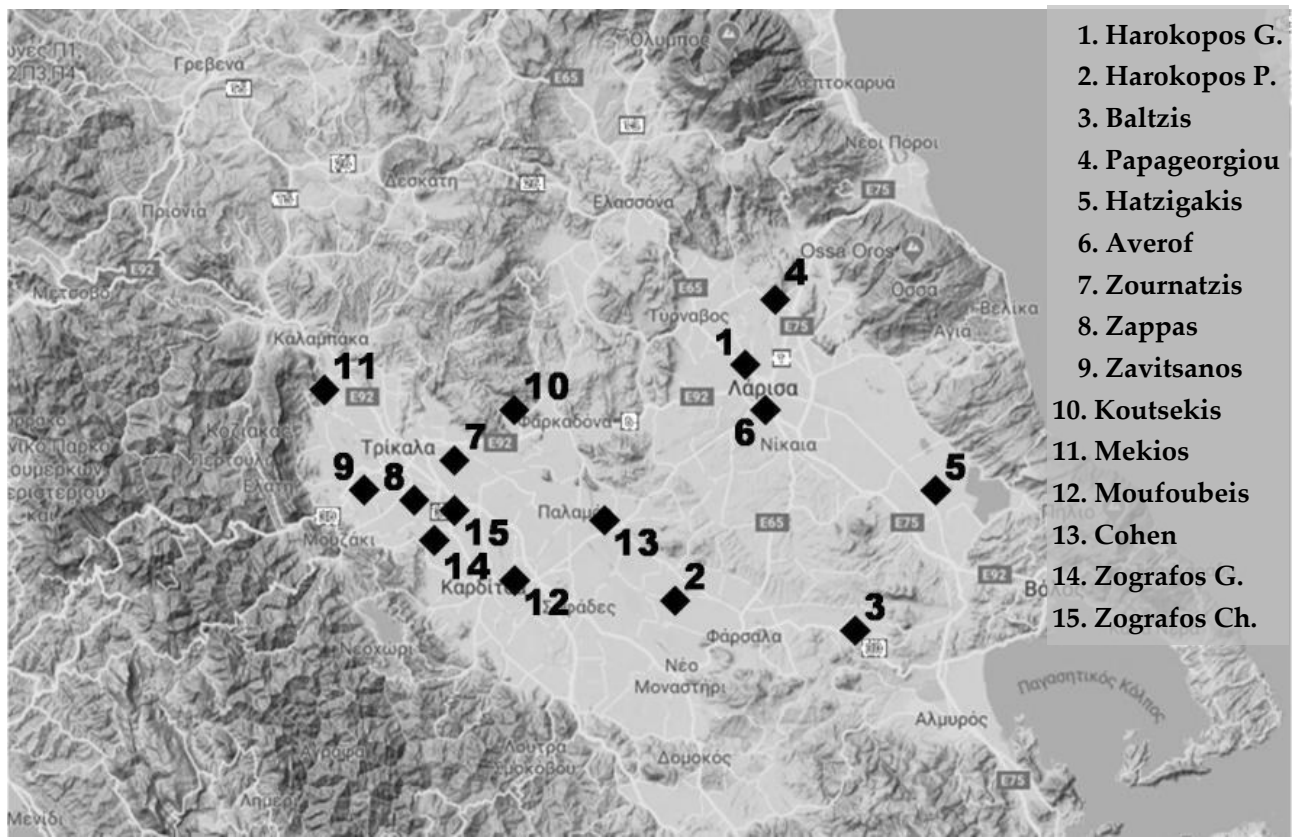

Figure 2. Distribution of the "konakia" in the Thessaly Region. Source: Processed by the authors.

Table 2. Key spatial and geographical characteristics of the "konakia" monuments.

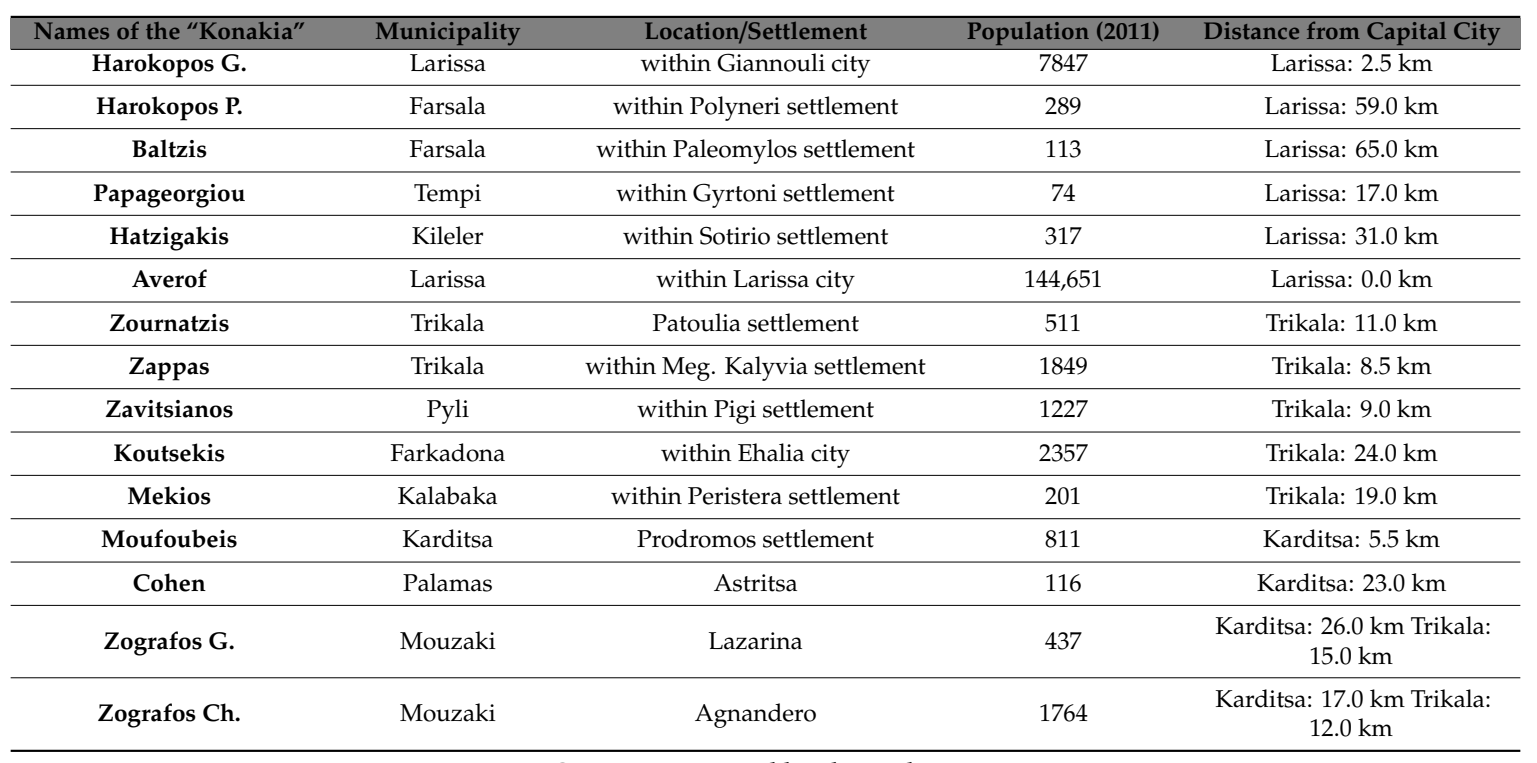

Source: processed by the authors.

The great majority of the "konakia" monuments are easily accessible via national and provincial roads, and they are in close proximity to important urban centres of the Region (average distance $10-25 \mathrm{~km}$ ).

Spatial features: the great majority of the "konakia" monuments are found in close proximity to or within rural settlements (some of which were developed to host the Greek refugee populations of the 1920s). However, there are also two "konakia" that are found in the Functional Urban Area (FUA) of Larissa (the capital of the Thessaly Region). The "konakia" were usually built within the perimeter of a settlement, i.e., they were not an integral part of a settlement. Today, however, following population growth in most of these areas, most "konakia" are found within the residential fabric of these settlements (see Figure 3). 

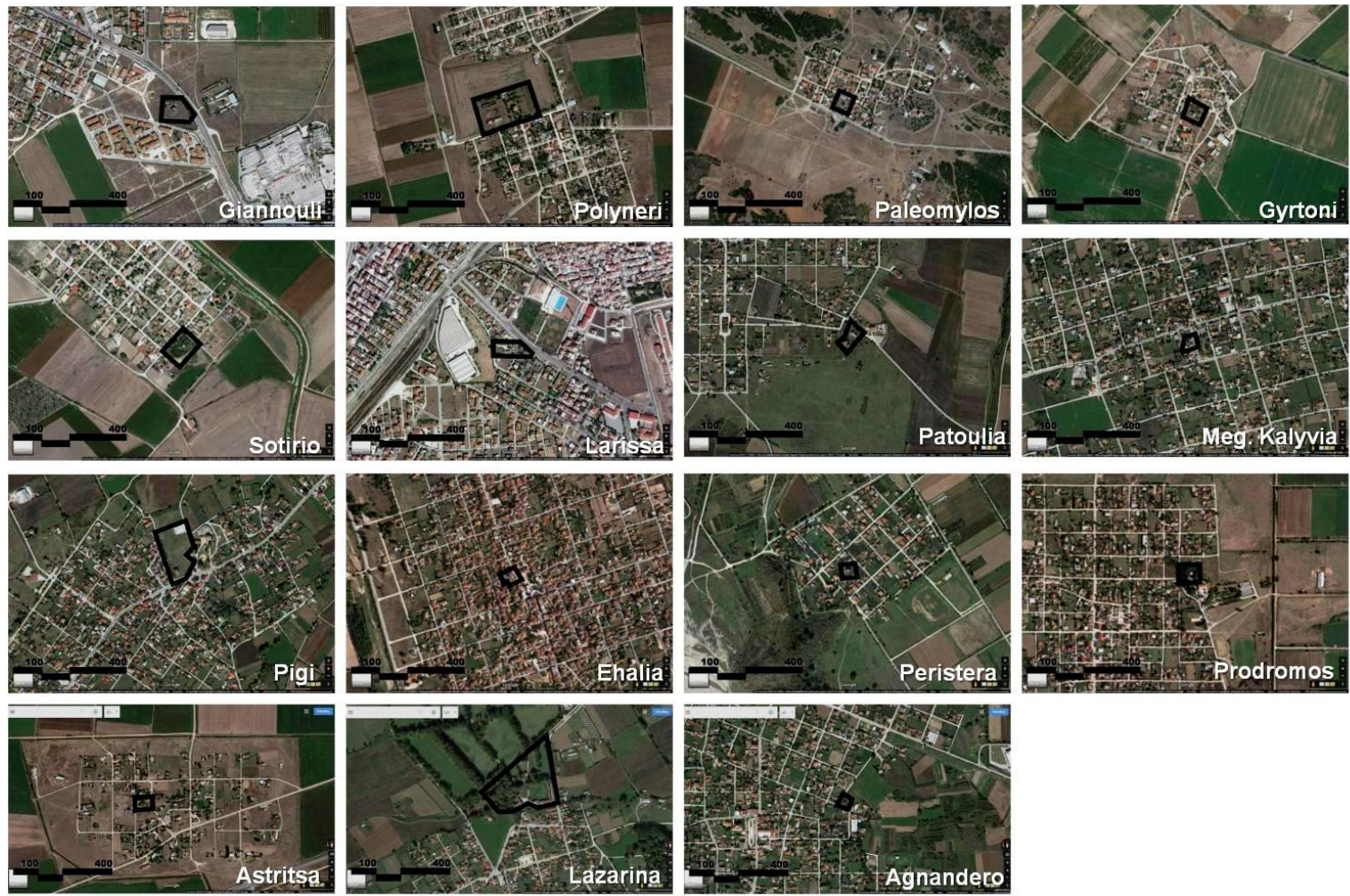

Figure 3. The location of the "konakia" monuments in relation to rural and urban developments. Source: processed by the authors.

In terms of spatial planning, only five (5) monuments are found in Municipalities having an approved Local Spatial Plan (or Urban Plan). These are the following: Harokopos in Giannouli (Official Gazette 225/ААП/2013); Averof in Larissa (Official Gazette 523/AАП/2009); Zavitsanos in Pigi (Official Gazette 54/AАП/2014); Moufoubeis in Prodromos (Official Gazette 220/ААП/2016); Zografos G. in Lazarina (Official Gazette 311/AAП/2012). In these cases (where a Local Spatial Plan has been approved), land-use planning and spatial organisation close to the "konakia" have taken into consideration the cultural value of these properties, and therefore set guidelines both for the regeneration and protection of areas in proximity and for the development of other cultural and leisure uses.

Protection status: As most of the "konakia" monuments constitute buildings of the late 19th and early 20th centuries, they are all designated as monuments of the modern built heritage of the country, and thus they are given protected status (Law 3028 of 2002). An exception to this is the Averof "konakia", which is not yet officially designated part of the modern built heritage of the country ${ }^{1}$. The designations for all the rest took place between 1979 and 2005, using a combination of provisions from Law 1469 of 1950 that was valid until Law 3028 was adopted in 2002. Specifically: (a) fourteen (14) (out of fifteen) "konakia" are designated as immobile modern monuments (built after 1830), according to L.3028/2002; and (b) thirteen (13) (out of fifteen) "konakia" are designated as historical preserved monuments and works of art, according to L.1469/1950.

1 The Averof "konakia" is not yet designated part of the modern built heritage of Thessaly, as it was built much later than the others (in the mid-20th century). Today, it is the property of the Municipality of Larissa, which is interested in launching a reconstruction and regeneration project. 
It should be mentioned, however, that even if these designations give both the remaining buildings and the land surrounding the "konakia" protected status, none of the designation Acts make reference to Buffer Zones, or to other regulations (spatial, etc.) for the protection of the monuments in question.

Architectural and morphological features: The "konakia" represent a common spatial structure, since in their original form, they all were building complexes that included a residential building and one or more auxiliary buildings within a large and fenced space. In eight (8) of the fifteen (15) cases, however, only the main building still stands. With regard to their architectural design and morphological features, they are usually two-storey structures (some also have a basement). The main building materials are: masonry in the external mosaic, tile roof, wooden floors and window frames, metal railings in the frames and openings. The architectural design of most buildings is influenced by late Greek neoclassical architecture (symmetry of plan and facades, tripartite organisation of facades, use of decorative elements such as pilasters, cornices, diazomes). A characteristic morphological element is the tower, which gives these properties a fortress character (six out of the fifteen monuments have a tower in the core building).

Property status: Despite their cultural value and the fact they are under protection status, most of the "konakia" monuments are still private properties-not necessarily under the ownership of descendants of the initial owners ("tsiflikades"). Three (3) of the "konakia" (Averof, Zappas and Zavitsanos) belong to the Municipal Authorities they are located in, while one of them (Moufoubeis "konakia") is state property (belonging to the Ministry of Culture).

Use and physical condition: The great majority of the "konakia" monuments (and especially those under private ownership) are in very bad condition (see Figure 4). Usually, they are abandoned properties that present extensive signs of neglect and damage (in most cases, only the external walls of the building remain). An exception to this rule is the Harokopos in Polyneri "konakia", private property that was recently restored and is currently used as a second home (residential use). As regards the other "konakia" (non-private), those that belong to Municipal Authorities have been reconstructed and now host leisure and cultural activities. The Zappas "konakia" operates as a Museum, the Averof "konakia" is used as a local cultural centre, while the Zavitsanos "konakia" is not currently in use. The Moufoubeis "konakia", which is state property, hosts the local offices of the Ephorate of Antiquities.

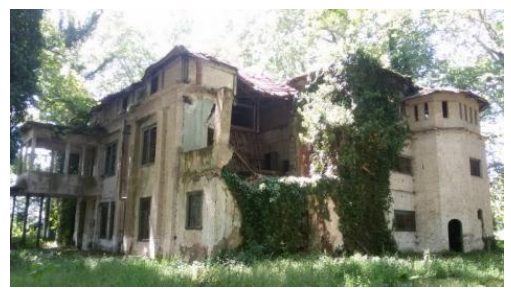

Zografou G.

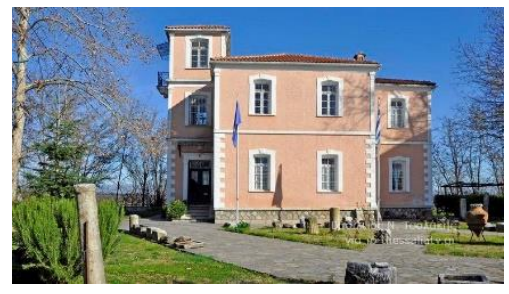

Moufoubeis

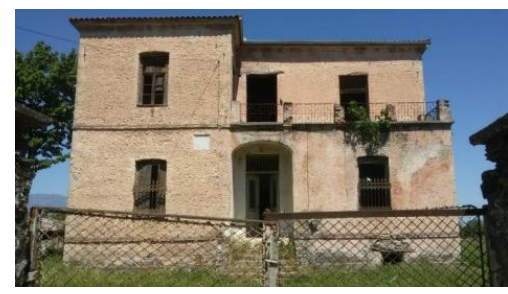

Zavitsanos

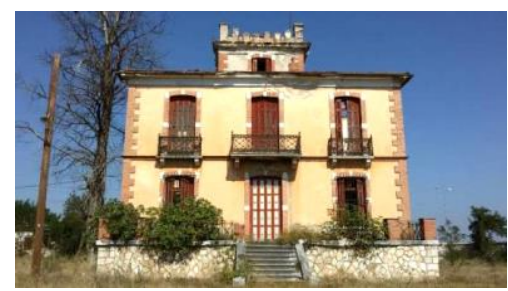

Harokopos G.

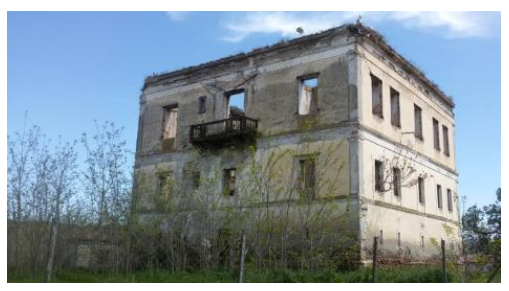

Papageorgiou

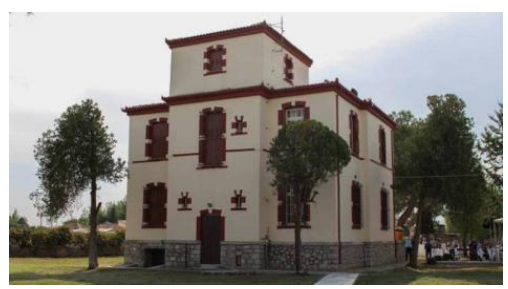

Harokopos P.

Figure 4. The use and condition of "konakia" today. Source: authors' archive.

\subsection{Evaluation and Discussion}

The "konakia" of the Thessalian plain are a unique type of monument in the area and throughout Greece. They have great historical value, as they relate directly or indirectly to critical events of their time, and also to historical figures who have played an important role in the political, economic and 
cultural life of the country. At the same time, they are remarkable architectural works, the majority having a morphology and construction different from the "folk" or traditional architecture of the 19th century. They can be considered either individually, or as a set of monuments, when they are concentrated in a certain geographical area and have common historical, spatial and morphological characteristics. In fact, as individual monuments, they are of great importance at the local level, while as a set of monuments, they have potential value and scope at both the regional and national level. However, research related to these monuments is still very limited and is not very thorough.

Being part of the modern built heritage of the Thessaly Region and Greece, the "konakia" monuments are protected by the Greek state (under the responsibility of the Ministry of Culture). However, even if the state proactively acted to place the "konakia" under protected status, this action would still be inadequate. In most cases, there are no designated buffer zones (imposing protection regulations), while the fact that the "konakia" were never considered (by the Ministry of Culture) as a set of monuments has played a negative role. In addition, due to the fact that they are usually private properties, they are deprived of appropriate management and protection actions (e.g., incentives and funding for rehabilitation). However, it is not only the cooperation between the public and private sectors that has so far failed, but also the cooperation among the central and local governments, which have never placed as much priority on the "konakia" monuments as on other cultural resources. As a result, most of the "konakia" are abandoned properties, either partially or completely neglected, and they constitute abandoned properties, even though they are fully acknowledged by the local community as being an important part of the modern built heritage of Thessaly.

Considering the nature and the challenges that "konakia" monuments face, a six (6)-step methodology for the wise management of the "konakia" monuments is presented below.

\subsection{Towards a Six (6)-Step Methodology for the Wise Management and Protection of the "Konakia" Monuments}

Considering the management and planning approaches, as well as the latest trends in evaluating cultural heritage, a six (6)-step methodology is proposed, for achieving wise management and the enhancement of the "konakia" the unique modern monuments of the Thessaly Region.

1st step: selection of the proper type of (re)use of the monument(s): following proper spatial, economic and real-estate analysis, and using economic valuation techniques, the most appropriate type of (re)use for the property(ies) in question should be ascertained. Moreover, it is in this step that -with the use of the abovementioned analysis and techniques-it should be decided whether the property should be expropriated by the State in order to better serve the proposed use (or if private and public cooperation is selected as a more appealing option).

2nd step: selection (or reconsideration) of the protection status and zoning: the type and degree of protection should be decided, in order to proceed to the necessary designations. In addition, it is also important to determine the type of protection zoning (delimitation of buffer zone, etc.), in order to apply suitable planning regulations.

3rd step: identification of the urban regeneration interventions: following the Historic Urban Landscape - and other management and planning — approaches, an urban regeneration plan should be drawn up in order to identify the types of interventions that are suitable for the property and its buffer area. The ultimate goal is to achieve integration into the spatial and cultural landscape.

4th step: introduction of the necessary amendments to the urban/local plan: usually, proposals and interventions needed for the upgrade and integration of a monument in its natural environment necessitate a set of amendments to the existing Urban/Local Plans (e.g., change of the city design, the land-use status, etc.).

5th step: selection of the proper financial tools: access to financial resources is the most crucial step, to ensure the implementation of all proposals (e.g., project studies, expropriations, restoration works, creation of thematic routes, etc.) 
6th step: identification of the marketing strategy: proper actions are necessary to promote the monument (e.g., via cultural routes) and make it attractive to the citizens and visitors. In this final step, proposals to achieved generation of income should be provided making long-term possible all types of interventions for the enhancement and sustainability of the monument.

\section{The Case of the Harokopos Tower "Konakia"}

\subsection{Key Information and Features}

"Harokopos tower" was selected as the case study because of its great historical and architectural value, and its spatial and geographical features. It was built in 1902 by Panagis A. Harokopos, who was an entrepreneur by occupation, but also a known philanthropist and politician. Because of his charities and donations to the Greek State, Panagis Harokopos is included in the list of the "national benefactors" of Greece.

"Harokopos tower" is located in the urban agglomeration of Larissa city (the capital of Thessaly Region), and more specifically in the area of Giannouli, a satellite settlement about $2.5 \mathrm{~km}$ to the north of Larissa (see Figure 5). In the late 19th century, Giannouli was a small settlement with only 71 residents (1984 census). Due to the strong migration wave of the 1920s (Greek expatriates coming from Asia Minor and East Thrace), Giannouli's population increased to 715 residents (1940 census). In addition, as a result, Giannouli obtained its first Urban Spatial Plan, which enabled the spatially organised development of the settlement [23]. In the 1970s, when Greece underwent another strong domestic migration wave, the population of Giannouli grew even more. It was then that "Harokopos tower", as well as the settlement of Giannouli, became part of the urban agglomeration of Larissa. Until the 2001 census, Giannouli was still an independent municipality, with a population of 10,022 inhabitants. After 2010, however, Giannouli became part of the Municipality of Larissa.

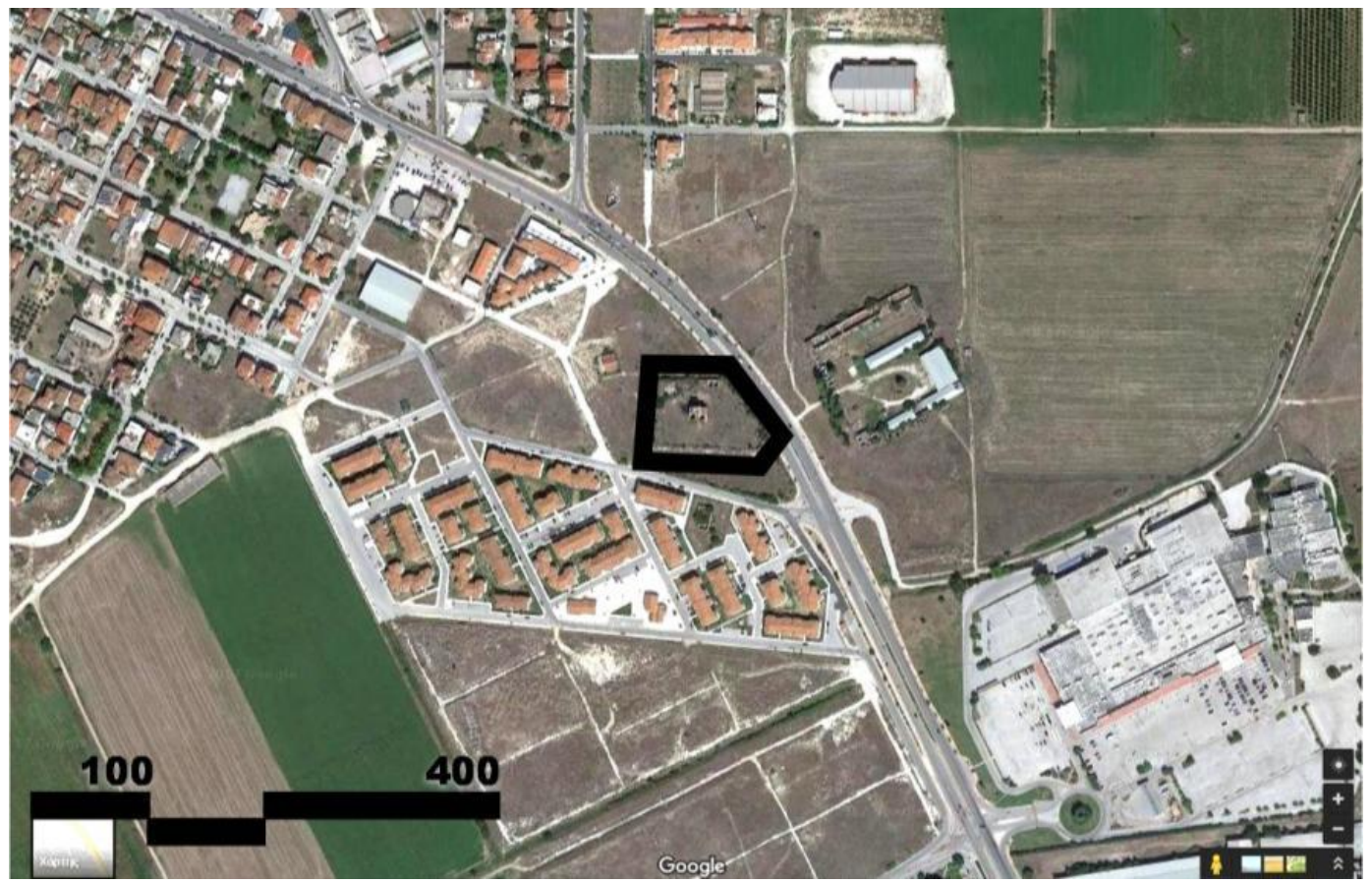

Figure 5. The location of "Harokopos tower" in relation to the rural and urban environment. Source: Processed by the authors.

Because of its historical and architectural value, in 1986, "Harokopos tower" was listed by the Ministry of Culture as work of art and as a historical monument; therefore, it was given protected 
status (Official Gazette 32/B/1986—decision $\Gamma / 30331 / 1944 / 3-1-1986$ ). Regarding its architectural features, the monument consists of the main residential building (located in the middle of a walled courtyard), and three smaller auxiliary buildings (along the north and western walls) (see Figure 5). The main residential building consists of two floors (on top of a semi-basement), having a symmetrical rectangular shape (about $14 \mathrm{~m}$ long and $12 \mathrm{~m}$ wide). It is a masonry construction with a wooden roof and ceramic roof tiles. On the top of the building (north façade) a small construction exists, resembling to a tower with battlements. The "Harokopos tower" in Giannouli, was designed in the Greek Neoclassical architectural style, by the architect Anastasios Metaxas (one of the most famous Greek architects of the early 20th century). This was a typical design for urban residences of the time, except for the tower, which was a distinct architectural element only used in the "konakia" that were built in the early 19th century [25].

As regards its ownership status, after Panagis Harokopos died in the early 1910s, the "tsiflikia" in Giannouli passed to his brother and later his brother's son. Soon after (in the 1920s), all the agricultural land (i.e., the "tsiflikia") was expropriated by the Ministry of Agriculture, and the descendants were left only with the "konakia" property (i.e., the land including the main residential building and the three auxiliary ones) (see Figure 5). Today, the property belongs to a local entrepreneur. However, it remains unused, with severe signs of abandonment, and high risk of collapse (see Figure 6).

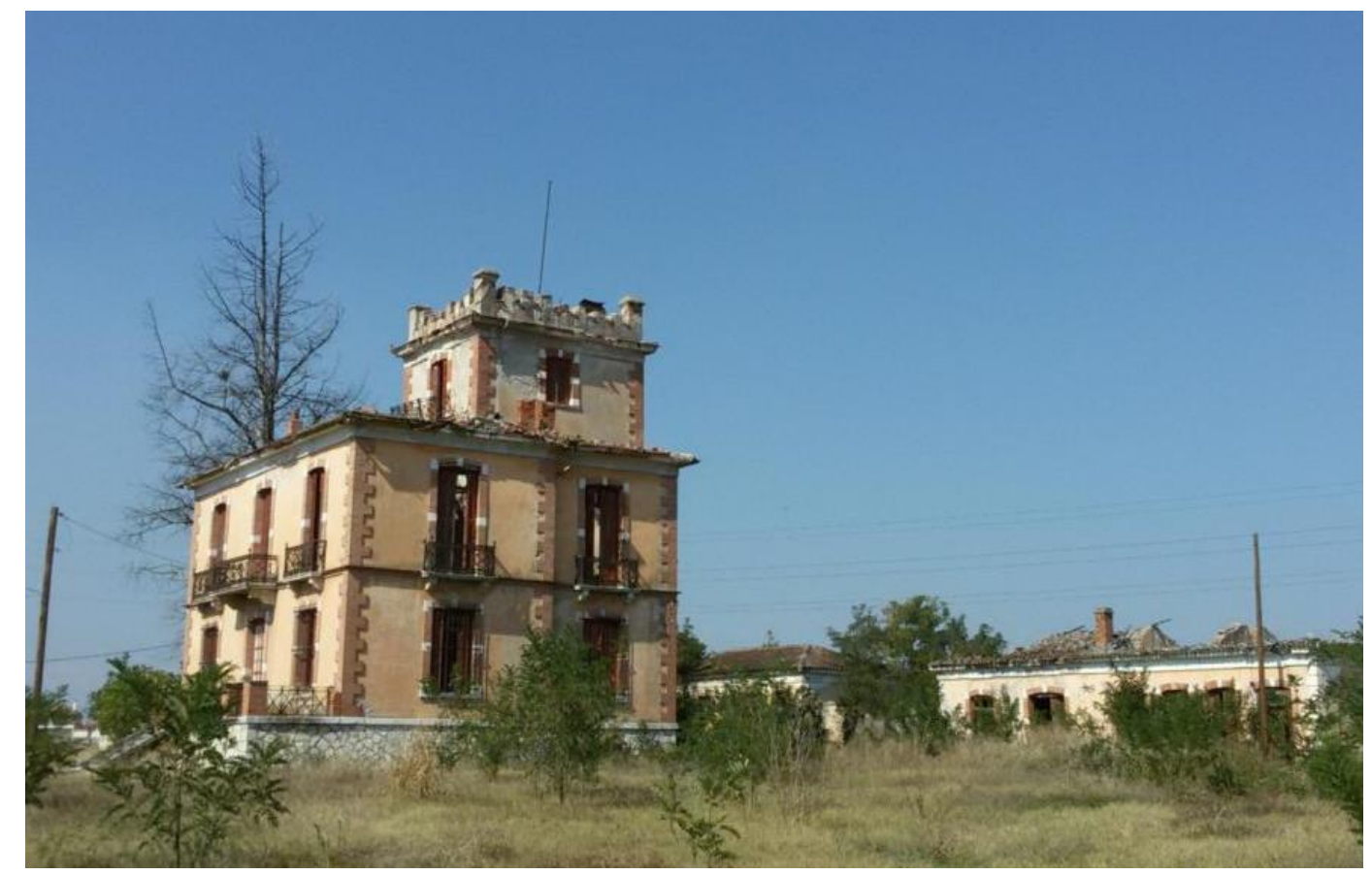

Figure 6. The Harokopos "konakia" in Giannouli. Source: Authors' archive.

As to planning provisions, according to the latest (and current) Urban Spatial Plan for Giannouli approved in 2013 (Official Gazette 225/AAП/2013), the "Harokopos tower" property covers a full block, surrounded by 5-metre-wide pedestrian streets to the north, west and south, and a main traffic axis to the east (see Figure 7). Only cultural uses are allowed in this block. The surrounding blocks to the north may host central-business-district uses, while the blocks to the west and south have a residential use. For the moment, however, most of the properties in these surrounding blocks are still vacant. Existing buildings that are found in the periphery of "Harokopos tower" have mixed uses, varying from residences and commercial buildings to the north, residences for social housing to the south and a cluster of retail stores along the highway. The vacant land surrounding the monument is mainly used for agriculture. 


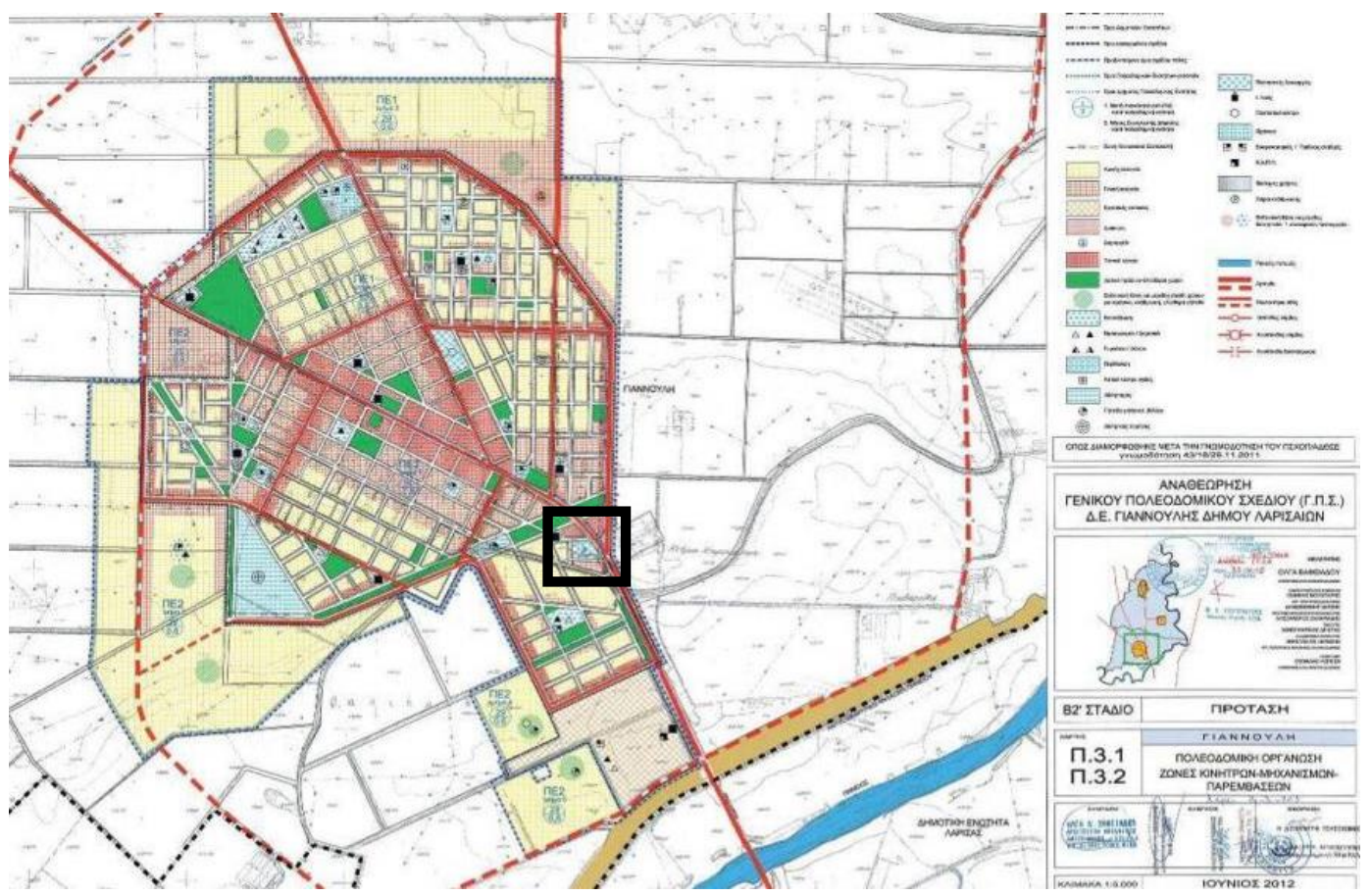

Figure 7. Spatial organisation of Giannouli according to the approved Local Spatial Plan. Source: Urban Spatial Plan of Giannouli (Official Gazette 225/AAP/2013).

\subsection{Management and Planning Proposals: Implementing the Six (6)-Step Methodology}

Considering the analysis performed in the previous section, as well as the methodology proposed in Section 3.4, the following proposals are made for the case of "Harokopos tower":

Selection of the proper type of (re)use of the monument(s): It is proposed that "Harokopos tower" should serve a cultural purpose as an innovative Historical Museum focusing on state-of-the-art digital technologies, including 3D representations, interactive displays, virtual reality and augmented reality displays, combined with exhibits about the history of the "konakia". The three levels of the main building could be converted into exhibition spaces, while the smaller buildings could house a shop, a cafeteria and offices. The construction of an underground extension would provide the necessary space for electrical and mechanical equipment and storage. The museum could host periodic exhibitions and organise various events (such as book presentations, history and art seminars, concerts, etc.) in the exhibition spaces and the open-air area around the buildings. An on-site cafeteria will also increase the museum's extroversion and facilitate its integration into the local community. Given the new use as a Museum, expropriation of the property is also needed. Expropriation could be undertaken by the Municipality of Larissa.

Selection (or reconsideration) of the protection status and zoning: in the case of "Harokopos tower", the existing protection status is considered sufficient. As regards the restoration that is needed, it could be undertaken by the local authorities (specifically, the Municipality of Larissa), in collaboration with the Service of Modern Monuments and Technical Works of Thessaly and the Central Region of Sterea Ellada (currently operating in Volos city).

Identification of the urban regeneration interventions: in order to integrate the monument into the surrounding urban and rural landscape and enhance its proposed cultural use as a museum, the following urban interventions are proposed: (a) preservation of the pedestrian streets around the site, (b) expropriation (by the Municipality) of the surrounding city blocks, to be converted to green spaces, and thus create a buffer zone between the monument and the built environment, (c) introduction of 
stricter land-use regulations and building rules in the buffer zone, (d) provision of a parking space in the vicinity of the monument, and (e) facilitation of the accessibility to the monument.

Introduction of the necessary amendments to the urban/local plan: The implementation of the above-mentioned proposals do not require any amendments to the existing Urban Plan.

Selection of the proper financial tools: The necessary funding could come from: the local municipality's Fund, the national Fund of Archaeological Proceeds, the National Green Fund, development programs (e.g., the European Structural and Investment Fund), special cultural and urban development EU funding programs, as well as sponsorships by the private sector and cultural institutions. At a later stage, financial resources would derive from tourist activities and various uses of the monument.

Selection of the proper marketing strategy: The main focus should be the inclusion of "Harokopos tower" (along with the rest of the "konakia" monuments and/or the rest of the cultural heritage in Thessaly) in Cultural Routes. Furthermore, the strategy should ensure collaboration and networking between the proposed museum and other museums, as well as with other types of cultural infrastructure/facilities in the Thessaly Region.

\section{Conclusion}

Thessaly is a Greek Region with a rich cultural heritage, both tangible and intangible, reflecting its long and interesting history throughout different periods of the past. Among this wide range of cultural heritage, a relatively less prominent category is the "konakia" that constitute modern monuments, built between late 19th and early 20th century.

Following a critical analysis and evaluation of the "konakia" monuments, a six (6)-step methodology was proposed, which could also be applied to other types of built heritage monuments either inside or outside urban settings. Of paramount importance, however, is the prior selection (or establishment) of a Management Authority that would be responsible, not only for implementing this (or any other) methodology, but also for raising public awareness and for ensuring cooperation among stakeholders from both the public and the private sector.

Considering the above, the greater stakes and challenges to be considered in the management and planning strategy that will be adopted (either for the "konakia" monuments or any other type of built heritage monument), should be: (a) how to ensure the necessary funding to address all management and planning needs, (b) how to achieve integration of the built heritage in question into the cultural landscape of an area and ultimately into the local tourism industry, (c) how to achieve integration of the monuments in question into the surrounding urban and rural landscape, and (d) how to protect (or even increase) the economic value of built heritage monuments, given that they are properties under protected status, and therefore have special limitations and needs in terms of restoration, use/exploitation and so on.

Author Contributions: Both authors contributed equally to this manuscript.

Funding: This research received no external funding.

Acknowledgments: The initial case study research was part of a postgraduate thesis project in the framework of the MSc in Urban Regeneration offered at the University of Thessaly (Department of Planning and Regional Development-DPRD). It was carried out in 2018 by Aikaterini Papandreou (Architect and Executive in the Thessaly Region Authority) and was supervised by Prof. Aspa Gospodini (Professor in DPRD) and Adjunct Asst. Prof. Marilena Papageorgiou.

Conflicts of Interest: The authors declare no conflict of interest.

\section{References}

1. Kunzmann, K.R. Culture, creativity and spatial planning. Town Plan. Rev. 2004, 75, 383-404. [CrossRef]

2. Geppert, A. Planning systems facing heritage issues in Europe: From protection to management, in the plural interpretations of the values of the past. Eur. Spat. Res. Policy 2004, 21, 9-12. [CrossRef] 
3. Gospodini, A.; Beriatos, E.; Raskou, E. Architectural heritage conservation: Progress in politics in Europe and new challenges for Greece. Aeichoros 2007, 6, 146-173. (In Greek)

4. Poulios, I. Discussing strategy in heritage conservation: Living heritage approach as an example of strategic innovation. J. Cult. Herit. Manag. Sustain. Dev. 2014, 4, 16-34. [CrossRef]

5. Poulios, I. Tangible Cultural Heritage Conservation, Local Community and Sustainable Development. In Heritage Conservation, Local Community and Sustainable Development; Poulios, I., Alivisatou, M., Arabatzis, G., Giannakidis, A., Karachalis, N., Mascha, E., Mouliou, M., Papadaki, M., Prosilis, C., Touloupa, S., Eds.; Association of Greek Academic Libraries: Athens, Greece, 2015; Available online: http://hdl.handle.net/ 11419/2395 (accessed on 1 September 2018). (In Greek)

6. UNESCO. New Life for Historic Cities: The Historic Urban Landscape Approach Explained. 2013. Available online: https://unesdoc.unesco.org/ark:/48223/pf0000220957 (accessed on 1 September 2018).

7. Bandarin, F.; Van Oers, R. (Eds.) Reconnecting the City: The Historic Urban Landscape Approach and the Future of Urban Heritage; John Wiley \& Sons: Hoboken, NJ, USA, 2014.

8. Taylor, K. The Historic Urban Landscape paradigm and cities as cultural landscapes. Challenging orthodoxy in urban conservation. Landsc. Res. 2016, 41, 471-480. [CrossRef]

9. Bandarin, F.; Van Oers, R. The Historic Urban Landscape: Managing Heritage in an Urban Century; John Wiley \& Sons: Hoboken, NJ, USA, 2012.

10. Kozlowski, J.; Vass-Bowen, N. Buffering external threats to heritage conservation areas: A planners perspective. Landsc. Urban Plan. 1997, 37, 245-267. [CrossRef]

11. Papageorgiou, M. Planning practices for the protection of cultural heritage in Greece: Lessons learnt from the Greek UNESCO sites. Eur. Spat. Res. Policy 2015, 22, 111-125. [CrossRef]

12. Claesson, S. The value and valuation of maritime cultural heritage. Int. J. Cult. Prop. 2011, 18, 61-80. [CrossRef]

13. Maarleveled, T.J. The maritime paradox: Does international heritage exist? Int. J. Herit. Stud. 2012, 18, 418-431. [CrossRef]

14. Thorsby, D. Cultural Capital. J. Cult. Econ. 2001, 23, 3-12. [CrossRef]

15. Navrud, S.; Ready, R. Valuing Cultural Heritage: Applying Environmental Valuation Techniques to Historic Buildings, Monuments, and Artifacts; Edward Elgar: Cheltenham, UK; Northampton, MA, USA, 2002.

16. Champ, P.; Boyle, K.J.; Brown, T.C. (Eds.) A Primer on Nonmarket Valuation; Kluwer: Boston, MA, USA, 2003.

17. Papageorgiou, M. Underwater cultural heritage facing spatial planning: Legislative and technical issues. Ocean Coast. Manag. 2018, 165, 195-202. [CrossRef]

18. Patronis, V. Greek Economical History; Association of Greek Academic Libraries: Athens, Greece, 2015; Available online: http://hdl.handle.net/11419/1700 (accessed on 1 September 2018). (In Greek)

19. Aroni-Tsichli, K. Agricultural Issue: Thessaly-New Lands 1909-1922. In History of the New Greek Nation: 1770-2000; Panagiotopoulos, B., Ed.; Hellenica Grammata: Athens, Greece, 2003; Volume 6, pp. 267-282. (In Greek)

20. Yelling, J.A. Common Field and Enclosure in England 1450-1850; Macmillan International Higher Education: London, UK, 1997.

21. Clark, G.; Clark, A. Common rights to land in England, 1475-1839. J. Econ. Hist. 2001, 61, $1009-1036$. [CrossRef]

22. Rossi-Doria, M. The land tenure system and class in southern Italy. Am. Hist. Rev. 1958, 64, 46-53. [CrossRef]

23. King, R.; Took, L. Land Tenure and Rural Social Change: The Italian Case (Landbesitzverhältnisse und sozialer Wandel auf dem Lande: Das Beispiel Italien). Erdkunde 1983, 37, 186-198. [CrossRef]

24. Niedertscheider, M.; Erb, K. Land system change in Italy from 1884 to 2007: Analysing the North-South divergence on the basis of an integrated indicator framework. Land Use Policy 2014, 39, 366-375. [CrossRef] [PubMed]

25. Georgitsogianni, E. Panagis A. Harokopos (1835-1911): His Life and Work; Nea Synora: Athens, Greece, 2000. (In Greek)

(C) 2019 by the authors. Licensee MDPI, Basel, Switzerland. This article is an open access article distributed under the terms and conditions of the Creative Commons Attribution (CC BY) license (http://creativecommons.org/licenses/by/4.0/). 